\title{
Integral use of Isabel grapes to elaborate new products with nutritional value and functional potential
}

\author{
Uso integral da uva Isabel na elaboração de novos produtos \\ com valor nutricional e potencial funcional
}

Francyeli Araújo Silva1, Graciele da Silva Campelo Borges ${ }^{2}$, Marcos dos Santos Lima Rita de Cássia Ramos do Egypto Queiroga4* (1), Maria Manuela Estevez Pintado5, Margarida Angélica da Silva Vasconcelos ${ }^{1}$

${ }^{1}$ Universidade Federal de Pernambuco (UFPE), Departamento de Nutrição, Recife/PE - Brasil

${ }^{2}$ Universidade Federal da Paraíba (UFPB), Centro de Tecnologia e Desenvolvimento Regional, Departamento de

Tecnologia de Alimentos, João Pessoa/PB, Brasil

${ }^{3}$ Instituto Federal do Sertão Pernambucano, Departamento de Tecnologia de Alimentos, Petrolina/PE - Brasil

${ }^{4}$ Universidade Federal da Paraíba (UFPB), Centro de Ciências da Saúde, Departamento de Nutrição, João

Pessoa/PB - Brasil

${ }^{5}$ Universidade Católica Portuguesa, Escola Superior de Biotecnologia, Porto - Portugal

*Corresponding Author: Rita de Cássia Ramos do Egypto Queiroga, Universidade Federal da Paraíba (UFPB), Centro de Ciências da Saúde, Departamento de Nutrição, Campus I, Cidade Universitária, CEP: 58033-455, João

Pessoa/PB - Brasil, e-mail: rcqueiroga@uol.com.br

Cite as: Silva, F. A., Borges, G. S. C., Lima, M. S., Queiroga, R. C. R. E., Pintado, M. M. E., \& Vasconcelos, M. A. S. (2021). Integral use of Isabel grapes to elaborate new products with nutritional value and functional potential. Brazilian Journal of Food Technology, 24, e2020041. https://doi.org/10.1590/1981-6723.04120

\begin{abstract}
The benefits of grape consumption are widely recognized and mostly due to phenolic compounds. These beneficial effects will depend on the bioaccessibility of these compounds on grape and its derivatives. This study elaborated two formulations of Isabel grape preparation: PAX (with agave and xylitol) and PS (with sucrose); and two formulations of Isabel grape flour: FAX (from the PAX process residues) and the FS (from the PS process residues). The products were analyzed regarding their nutritional and antioxidant properties; their phenolic compounds' bioaccessibility was also verified through a simulated digestion model. The preparation and flour exhibited relevant

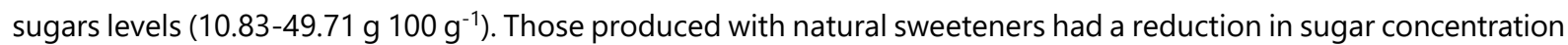
of $51 \%$ and $29 \%$ for preparation and flour, respectively, compared to formulations with sucrose, with the high fiber

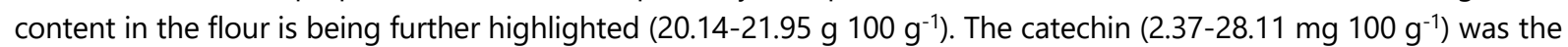

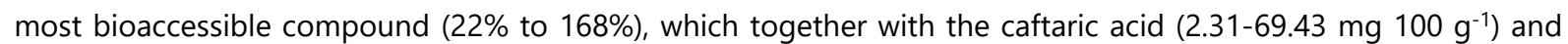
malvidin 3-glucoside (8.65-16.47 mg $\left.100 \mathrm{~g} \mathrm{~g}^{-1}\right)$ represent the compounds observed in greater quantity. The preparations showed higher bioaccessibility regarding grapes and flours for most of the phenolic compounds. Furthermore, the products elaborated presented higher values of anthocyanins and antioxidant activity than the in natura grape, highlighting the beneficial effect of grape processing.
\end{abstract}

Keywords: Grape products; Full use; Natural sweeteners; Fiber diet; Bioactive compounds; Bioaccessibility. 


\section{Resumo}

Os benefícios do consumo da uva já são amplamente reconhecidos e devem-se em grande parte aos compostos fenólicos. Esses efeitos benéficos irão depender da bioacessibilidade desses compostos na uva e em seus derivados. Foram elaboradas duas formulações de preparado de uva Isabel: PAX (com agave e xilitol) e PS (com sacarose); e duas formulações de farinha de uva Isabel: FAX (a partir do resíduo do processamento do PAX) e FS (a partir do resíduo do processamento do PS). Os produtos foram analisados quanto às suas propriedades nutricionais e antioxidantes, e a bioacessibilidade de seus compostos fenólicos foi verificada por meio de um modelo de digestão simulada. O preparado e a farinha apresentaram níveis relevantes de açúcares (10,83-49,71 g $\left.100 \mathrm{~g}^{-1}\right)$, sendo que aqueles produzidos com adoçantes naturais tiveram uma redução na concentração dos açúcares de $51 \%$ e $29 \%$ para o preparado e a farinha, respectivamente, em comparação com formulações com sacarose, destacando-se

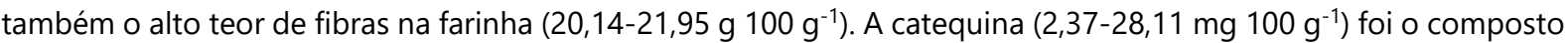
mais bioacessível (22\% a 168\%), que juntamente com o ácido caftárico (2,31-69,43 mg $100 \mathrm{~g}^{-1}$ ) e o malvidina 3-glicosídeo (8,65-16,47 mg $\left.100 \mathrm{~g}^{-1}\right)$ representam os compostos observados em maior quantidade. O preparado teve maior bioacessibilidade tanto em relação à uva quanto à farinha para a maioria dos compostos fenólicos. Além disso, os produtos elaborados apresentaram maiores valores de antocianinas e atividade antioxidante que a uva in natura, destacando o efeito benéfico do processamento da uva.

Palavras-chave: Produtos de uva; Aproveitamento integral; Adoçantes naturais; Fibra dietética; Compostos bioativos; Bioacessibilidade.

\section{Introduction}

Considering the increasing concern about environmental issues, the integral utilization of fruits has been highly recommended for its best use and lowest accumulation of solid residues causing a lower environmental impact. Thus, it is appealing to consider the use of fruits residues as potential substrates for obtaining products with high added value (Sette et al., 2020), such as the bagasse obtained from grape processing, which retains a large part of the phenolic compounds, about $20 \%$ to $30 \%$ in the peels and $60 \%$ to $70 \%$ in the seeds (Sousa et al., 2014; Valero-Cases \& Frutos, 2017).

The food industry has expanded its interest in the production of grape derivatives, such as wines, juices and jams, due to its rich composition in bioactive compounds (Haas et al., 2018). Therefore, it is important to adopt strategies to the utilization of all nutritional component of the raw material (Pizzolato et al., 2012). The Isabel grape (Vitis labrusca L.) is very cultivated and is mainly used for in natura consumption and juice production (Silva et al., 2017). Whereas the scope of beneficial effects on the body will depend on the bioaccessibility of phenolic compounds (Ribas-Agustí et al., 2018), has been increasingly studied the simulated digestion effect on these compounds of the grape (Gomes et al., 2019; Pešić et al., 2019).

Considering the production of foods with better nutritional quality, another strategy employed for this purpose is the replacement of refined sugars with natural dietary sweeteners, such as agave and xylitol. These are considered healthier alternatives that can reduce risk factors associated with health problems such as obesity, hypertension, diabetes, caries and cardiovascular diseases (Akesowan, 2015). Such natural sweeteners may be used, for example, in the production of fruit derivatives to obtain products with added value and properties which meet the growing demand for nutritious and healthy foods (Viana et al., 2015).

Thus, given the importance of the integral use of foods and the benefits of grape consumption, bioactive compounds and antioxidant activity must be preserved after processing. Therefore, this study elaborated preparation and flour with integral Isabel grape use and added with different sweeteners, evaluated the impacts of their processing and analyzed the bioaccessibility of phenolic compounds and antioxidant potential. 


\section{Materials and methods}

\subsection{Reagents}

Folin-Ciocalteu reagent, pepsin, $\alpha$-amylase, pancreatin, glycodeoxycholate, taurodeoxycholate and taurocholate were obtained from Sigma-Aldrich (St. Louis, Missouri, USA). 2,2-Diphenyl-1-picrylhydrazyl (DPPH) and 6-hydroxy-2,5,7,8-tetramethylchromane-2-carboxyl acid (Trolox) were obtained from SigmaAldrich (Hamburg, Germany), and 2,4,6-tri (2-pyridyl)-s-Triazine (TPTZ) was obtained from Sigma-Aldrich (Milan, Italy). Methanol and other reagents were obtained from Neon (São Paulo, Brazil).

The standards of phenolic compounds for high-performance liquid chromatography (HPLC) (catechin, epigallocatechin gallate, procyanidin B1, B2 and A2, quercetin 3-glucoside, rutin, kaempferol glucoside, gallic, caffeic, caftaric, and chlorogenic acids, trans-resveratrol naringenin, hesperidin, delphinidin 3-glucoside, malvidin 3-glucoside, pelargonidin 3-glucoside, peonidin 3-glucoside), as well as the standards of sugars and organic acids (maltose, glucose, fructose, citric, tartaric, malic, succinic and formic acid) were obtained from Sigma-Aldrich (St. Louis, MO, USA).

\subsection{Samples}

Isabel grapes were acquired from Paraibana Company of Supply and Agricultural Services (EMPASA), located in the city of João Pessoa-PB, northeastern Brazil ( $07^{\circ} 06^{\prime} 54^{\prime \prime} \mathrm{S}, 34^{\circ} 51^{\prime} 47^{\prime \prime} \mathrm{W}$ ) at an altitude of $47 \mathrm{~m}$. The grapes in commercial maturation stages were selected, washed in running water and sanitized in chlorinated water solution for 15 minutes at the rate of $100 \mathrm{ppm}$ of sodium hypochlorite. Agave syrup and xylitol were commercially purchased.

\subsubsection{Processing of the grape preparation and flour}

In natura Isabel grapes were used to elaborate two formulations. For the preparation with agave and xylitol

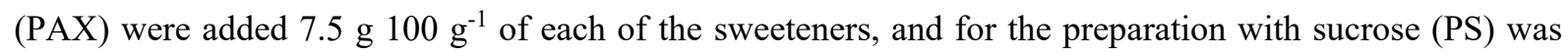

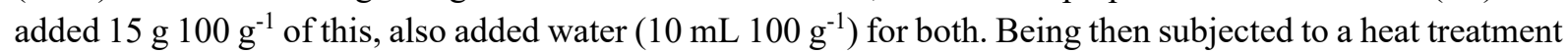
$\left(92.5^{\circ} \mathrm{C} / 3 \mathrm{~min}\right)$ in a water bath, then cooled in an ice bath, crushed in a blender for 2 minutes and sieved in a 20 mesh sieve. After processing, this showed a solids content ( ${ }^{\circ}$ Brix) of 24.20 for PAX and 26.90 for PS. The Isabel grape preparations were packed in polyethylene containers and stored under refrigeration $\left(5^{\circ} \mathrm{C} \pm 1{ }^{\circ} \mathrm{C}\right)$ until further analysis.

Filtration retention (peels and seeds) of the preparation was dried in an air circulation oven at $60{ }^{\circ} \mathrm{C}$ until

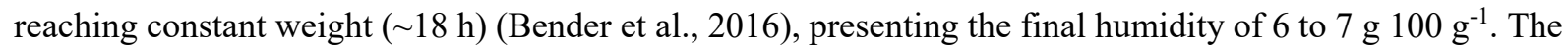
resulting product was then ground in a food processor and sieved in a 28 mesh sieve, yielding the FAX flour from the PAX process residues and the FS flour from the PS, thereafter, they were packed in polyethylene containers and stored under refrigeration $\left(5^{\circ} \mathrm{C} \pm 1{ }^{\circ} \mathrm{C}\right)$ until further analysis.

\subsection{Physicochemical analysis}

The physicochemical characterization of Isabel grape preparation and flour included determination of total solids, proteins, lipids, ash, soluble and insoluble fibers, $\mathrm{pH}$ and color, according to methodology recommended by the Association of Official Analytical Chemist (2016).

\subsubsection{Determination of sugars and organic acids}

The sugars and organic acids were extracted from the grape and the products using $4.0 \mathrm{mM} / \mathrm{L}$ sulfuric acid in ultrapure water, and filtered on a $0.45 \mu \mathrm{m}$ membrane (PTFE) (Batista et al., 2018). The extracts were analyzed by HPLC using an Agilent chromatograph (model 1260 Infinity LC; Agilent Technologies Inc., 
Santa Clara, CA, USA) coupled to a diode arrangement detector (G1315D model) and refractive index detector (G1362A model). The other analytic conditions were an Agilent Hi-Plex H column $(7.7 \times 300 \mathrm{~mm}, 8 \mu)$ with a mobile phase of $\mathrm{H}_{2} \mathrm{SO}_{4} 4 \mathrm{mmol} \mathrm{L}^{-1}$ in ultrapure water and a flow rate of $0.7 \mathrm{~mL} \mathrm{~min}^{-1}$. The temperature was maintained at $50{ }^{\circ} \mathrm{C}$ with a sample injection volume of $10 \mu \mathrm{L}$. Data were processed using Open LAB CDS Cessation Edition software (Agilent Technologies, Santa Clara, USA). The detection of the compounds was performed by comparing their retention times with external standards (Ball et al., 2011).

\subsection{Phenolic extraction}

The extraction was adapted from the methodology described by Pintać et al. (2018). Samples of fresh grapes $(1.5 \mathrm{~g})$ and grape flour $(1 \mathrm{~g})$ were extracted with $10 \mathrm{ml}$ of methanol/water $(85: 15, \mathrm{v} / \mathrm{v})$, while grape preparation $(1.5 \mathrm{~g})$ was extracted with $8.5 \mathrm{~mL}$ of methanol. They were then subjected to extraction in an ultrasonic bath (UNIQUE, model USC - 1800, Brazil) at $40 \mathrm{kHz}$ for $30 \mathrm{~min}$ and $25{ }^{\circ} \mathrm{C}$. Samples were centrifuged at 5500g for 15 min (model SL-701, Solab, São Paulo, Brazil) and the supernatants were collected. Extraction was repeated 2 more times under the same conditions. The supernatants were then combined, the removal of the solvents was carried out in a rotary evaporator (Fisatom 802, São Paulo, Brazil). The extracts were re-suspended in $2 \mathrm{~mL}$ of methanol and filtered through a $0.45 \mu \mathrm{m}$ syringe filter (PTFE). These extracts were stored in a freezer at $-20 \pm 2{ }^{\circ} \mathrm{C}$ to determine the profile of phenolic compounds, the content of total monomeric anthocyanins and the antioxidant activity.

\subsection{Monomeric anthocyanins}

The monomeric anthocyanins (MA) were quantified using the differential $\mathrm{pH}$ method (Giusti \& Wrolstad, 2001). The readings were performed at 510 and $700 \mathrm{~nm}$ absorbances, with 1 and $4.5 \mathrm{pH}$ buffers in a spectrophotometer (model Cary 60, Agilent Technologies, Malaysia). Total MA was calculated according to the following Equation 1:

$M A=A \times M W \times 1000 /(\varepsilon \times C)$

Where $\mathrm{A}$ is the absorbance $=\left(A_{515}-A_{700}\right)_{\mathrm{pH}} 1.0-\left(A_{515}-A_{700}\right)_{\mathrm{pH}} 4.5 ; \mathrm{MW}$ is the molecular weight of the malvidin 3-glucoside $=493.2 ; \varepsilon$ is the molar absorptivity of malvidin 3 -glucoside $=28,000$; and $C$ is the buffer concentration in $\mathrm{mg} / \mathrm{mL}$. The anthocyanin content was expressed as $\mathrm{mg}$ of malvidin 3-glucoside/100 $\mathrm{g}$.

\subsection{Antioxidant activity}

Total antioxidant activity was analyzed by investigation of the ability to sequester free radicals DPPH (2,2-diphenyl-1-picrylhydrazyl) using a modified version of the method by Brand-Williams et al. (1995). The iron ion reduction potential $\left(\mathrm{Fe}^{+2}\right.$ ) (FRAP) was determined by the method described by Rufino et al. (2006). The ability to deactivate oxygen radicals (ORAC) was determined by the method adapted from Zulueta et al. (2009).

\subsection{Determination of the phenolic compounds profile}

The phenolic compounds were analyzed according to a methodology adapted by Dutra et al. (2018) using an Agilent 1260 Infinity LC liquid chromatograph (Agilent Technologies, Santa Clara, USA) coupled to a diode arrangement detector (DAD) (model G1315D). Data were processed using the OpenLAB CDS ChemStation Edition software (Agilent Technologies, Santa Clara, USA). The Zorbax Eclipse Plus RP-C18 $(100 \times 4.6 \mathrm{~mm}, 3.5 \mu \mathrm{m})$ column and the Zorbax C18 $(12.6 \times 4.6 \mathrm{~mm}, 5 \mu \mathrm{m})$ pre-column (Zorbax, USA) were used. The mobile phase was composed of the following solutions: $0.1 \mathrm{M}$ phosphoric acid, $\mathrm{pH}=2.0$ (A) and methanol with $0.5 \%$ phosphoric acid (B). The temperature was $35^{\circ} \mathrm{C}$ and the sample injection volume was $20 \mu \mathrm{L}$, previously diluted in phase A and filtered through a $0.45 \mu \mathrm{m}$ membrane (Millex Millipore, Barueri, 
SP, Brazil). The solvent flow rate was $0.8 \mathrm{~mL} / \mathrm{min}$. The gradient used in the separation was 0 to $5 \mathrm{~min}: 5 \%$ B; 5-14 min: $23 \%$ B; 14 to $30 \mathrm{~min}: 50 \%$ B; 30 to $33 \mathrm{~min}: 80 \% \mathrm{~B}$. Detection of compounds was performed at $220,280,320,360$ and $520 \mathrm{~nm}$, and the identification and quantification by comparison with external standards.

\subsection{Simulation of in vitro gastrointestinal digestion}

The in vitro digestion procedure simulated the gastrointestinal physiological conditions in three sequential phases (oral, gastric and small intestine) as described by Dutra et al. (2017). Samples aliquots (10 $\mathrm{g}$ for flours and $20 \mathrm{~g}$ for preparations and grape) were mixed with $5 \mathrm{ml}$ of saline solution $\left(2.38 \mathrm{~g} \mathrm{Na}_{2} \mathrm{HPO}_{4}, 0.19 \mathrm{~g}\right.$ $\mathrm{KH}_{2} \mathrm{PO}_{4}, 8 \mathrm{~g} \mathrm{NaCl}$ and $200 \mathrm{U} \mathrm{L}^{-1} \alpha$-amylase) in amber bottles. The mixture was stirred for $10 \mathrm{~min}$ in a water bath at $37 \pm 2{ }^{\circ} \mathrm{C}$ at $95 \mathrm{rpm}$. Samples were then acidified to $\mathrm{pH} 2.0$ with $1 \mathrm{ml}$ of pepsin solution $(13 \mathrm{mg}$ of pepsin in $5 \mathrm{ml}$ of $0.1 \mathrm{~mol} \mathrm{~L}^{-1} \mathrm{HCl}$ ) to a final volume of $5 \mathrm{ml}$ and incubated at $37^{\circ} \mathrm{C}$, with shaking at $95 \mathrm{rpm}$ for $1 \mathrm{~h}$ to simulate gastric digestion. At the end of gastric digestion, the mixture was immediately cooled in an ice bath, and a $1 \mathrm{ml}$ aliquot was removed and stored at $-18 \pm 2{ }^{\circ} \mathrm{C}$. The remaining sample was submitted to the simulation of digestion in the small intestine. Where $5 \mathrm{~mL}$ of pancreatin $(0.12 \mathrm{~g})$ and bile salts $(40 \mathrm{mg}$ glycodeoxycholate in $1 \mathrm{~mL}$ saline), taurodeoxycholate ( $25 \mathrm{mg}$ in $1 \mathrm{~mL}$ saline), and taurocholate (40 mg in $1 \mathrm{~mL}$ saline) were added in polyethylene tubes with the samples, and then incubated under agitation $(95 \mathrm{rpm})$ at $37^{\circ} \mathrm{C}$ for $2 \mathrm{~h}$ to complete the intestinal phase. Bioaccessibility was expressed as a percentage and determined according to the following Equation 2):

Bioaccessibility $(\%)=($ bioaccessible fraction / non - bioaccessible initial fraction $) \times 100$

Where bioaccessible corresponds to the concentration of phenolic compounds in the digested portion, and non-bioaccessible to the concentration of phenolic compounds in the initial sample (before digestion).

\subsection{Statistical analyzes}

The experiments were performed in triplicate with independent replicates. Data were expressed as mean \pm standard deviation of the three replicates. The results were evaluated by analysis of variance (ANOVA), and significant differences $(p \leq 0.05)$ between averages were identified by Student's t-test for the physicochemical parameters and by Tukey test for the other analyzes. Correlations were calculated by the Pearson correlation coefficient (r). Principal component analysis (PCA) was used to show the correlation matrix between phenolic compounds and antioxidant activity in grape products and their digested fraction. The data were analyzed using the XLstat software version 2018.5.

\section{Results and discussion}

\subsection{Nutritional composition and sugars and organic acids profile}

The values for the nutritional composition and the sugars and organic acids profile of Isabel grape preparation and flour are presented in Table 1. Concerning sugars (Table 1), in particular glucose and fructose, the grape preparation added of sucrose (PS) had higher levels $(p \leq 0.05)$ when compared to grape preparation added of agave and xylitol (PAX), as expected since sucrose is a disaccharide that when hydrolyzed gives rise to glucose and fructose molecules.

The flour resulting from the residue of formulation with agave and xylitol (FAX) presented higher values $(p \leq 0.05)$ of soluble, insoluble and total fiber. Both FS and FAX had a high dietary fiber content $(20$ to $22 \mathrm{~g}$ $\left.100 \mathrm{~g}^{-1}\right)$ and can be considered a food with high fiber content $\left(6 \mathrm{~g}^{100 \mathrm{~g}^{-1}}\right)$ (Food and Agriculture Organization, 2010). Besides, the fibers found in grape flour can be considered more interesting for 
consumption than those found in other flours because they are associated with polyphenols, which have antioxidant activity (Sousa et al., 2014).

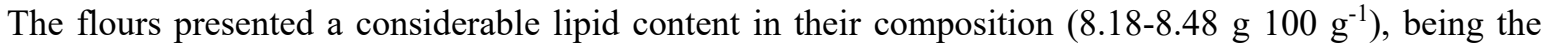
highest percentage of these lipids from grape seeds (Sousa et al., 2014). Low pH (3.94 to 3.99) and humidity

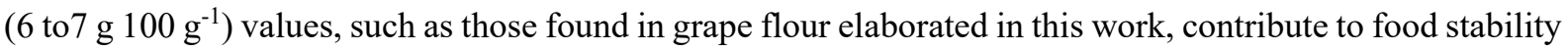
and increase its shelf life, since they reduce the risk of enzymatic, non-enzymatic and microbiological alterations, providing its greater applicability as food industry ingredient (Selani et al., 2014).

Table 1. Nutritional composition, instrumental color and profile of sugars and organic acids of the Isabel grape preparation and flour.

\begin{tabular}{|c|c|c|c|c|}
\hline \multirow{2}{*}{$\begin{array}{c}\text { Parameters } \\
\left(\text { g } 100 \mathrm{~g}^{-1}\right)\end{array}$} & \multicolumn{2}{|c|}{ Preparation } & \multicolumn{2}{|c|}{ Flour } \\
\hline & PS & PAX & FS & FAX \\
\hline Total solids & $26.07 \pm 0.05^{\mathrm{a}}$ & $23.50 \pm 0.03^{b}$ & $92.19 \pm 0.02^{\mathrm{B}}$ & $93.62 \pm 0.05^{\mathrm{A}}$ \\
\hline Proteins & $0.49 \pm 0.04^{\mathrm{a}}$ & $0.49 \pm 0.04^{\mathrm{a}}$ & $4.80 \pm 0.01^{\mathrm{A}}$ & $4.20 \pm 0.08^{\mathrm{B}}$ \\
\hline Lipids & $2.86 \pm 0.01^{\mathrm{a}}$ & $1.66 \pm 0.01^{\mathrm{b}}$ & $8.48 \pm 0.08^{\mathrm{A}}$ & $8.18 \pm 0.10^{\mathrm{A}}$ \\
\hline Ash & $0.37 \pm 0.01^{\mathrm{a}}$ & $0.25 \pm 0.01^{\mathrm{b}}$ & $1.93 \pm 0.01^{\mathrm{A}}$ & $1.66 \pm 0.01^{\mathrm{B}}$ \\
\hline Soluble fiber & - & - & $3.45 \pm 0.15^{\mathrm{B}}$ & $3.95 \pm 0.30^{\mathrm{A}}$ \\
\hline Insoluble fiber & - & - & $16.69 \pm 0.01^{\mathrm{B}}$ & $18.01 \pm 0.01^{\mathrm{A}}$ \\
\hline Total fiber & $0.62 \pm 0.01^{\mathrm{a}}$ & $0.63 \pm 0.01^{\mathrm{a}}$ & $20.14 \pm 0.15^{\mathrm{B}}$ & $21.95 \pm 0.31^{\mathrm{A}}$ \\
\hline \multicolumn{5}{|l|}{ Sugars } \\
\hline Maltose & $0.01 \pm 0.01$ & $<$ LOD & $0.03 \pm 0.01^{\mathrm{A}}$ & $0.04 \pm 0.01^{\mathrm{A}}$ \\
\hline Glucose & $11.29 \pm 0.48^{\mathrm{a}}$ & $4.16 \pm 0.08^{b}$ & $25.41 \pm 0.53^{\mathrm{A}}$ & $13.91 \pm 0.26^{\mathrm{B}}$ \\
\hline Fructose & $11.11 \pm 0.46^{\mathrm{a}}$ & $6.67 \pm 0.13^{b}$ & $24.27 \pm 0.45^{\mathrm{A}}$ & $21.17 \pm 0.37^{\mathrm{B}}$ \\
\hline Total & $22.41 \pm 0.94^{\mathrm{a}}$ & $10.83 \pm 0.22^{b}$ & $49.71 \pm 0.98^{\mathrm{A}}$ & $35.12 \pm 0.63^{\mathrm{B}}$ \\
\hline \multicolumn{5}{|l|}{ Organic acids } \\
\hline Citric acid & $0.01 \pm 0.01^{\mathrm{a}}$ & $0.01 \pm 0.01^{\mathrm{a}}$ & $0.13 \pm 0.01^{\mathrm{A}}$ & $0.01 \pm 0.01^{\mathrm{B}}$ \\
\hline Tartaric acid & $0.50 \pm 0.02^{\mathrm{a}}$ & $0.43 \pm 0.01^{\mathrm{a}}$ & $0.98 \pm 0.02^{\mathrm{A}}$ & $0.88 \pm 0.01^{\mathrm{B}}$ \\
\hline Malic acid & $0.28 \pm 0.01^{\mathrm{a}}$ & $0.21 \pm 0.01^{\mathrm{b}}$ & $0.59 \pm 0.01^{\mathrm{B}}$ & $0.66 \pm 0.01^{\mathrm{A}}$ \\
\hline Succinic acid & $0.03 \pm 0.01$ & $<$ LOD & $<$ LOD & $<\mathrm{LOD}$ \\
\hline Formic acid & $0.02 \pm 0.01$ & $<$ LOD & $0.04 \pm 0.01^{\mathrm{A}}$ & $0.03 \pm 0.01^{\mathrm{A}}$ \\
\hline Total & $0.85 \pm 0.03^{\mathrm{a}}$ & $0.64 \pm 0.01^{\mathrm{b}}$ & $1.74 \pm 0.03^{\mathrm{A}}$ & $1.59 \pm 0.01^{\mathrm{B}}$ \\
\hline \multicolumn{5}{|l|}{ Color } \\
\hline $\mathrm{L}^{*}$ & $14.39 \pm 0.18^{b}$ & $15.77 \pm 0.11^{\mathrm{a}}$ & $8.25 \pm 0.24^{\mathrm{A}}$ & $8.30 \pm 0.24^{\mathrm{A}}$ \\
\hline$a^{*}$ & $3.54 \pm 0.23^{\mathrm{a}}$ & $4.28 \pm 0.11^{\mathrm{a}}$ & $13.11 \pm 0.23^{\mathrm{A}}$ & $11.21 \pm 0.09^{\mathrm{B}}$ \\
\hline$b^{*}$ & $0.81 \pm 0.01^{\mathrm{a}}$ & $1.11 \pm 0.16^{\mathrm{a}}$ & $5.60 \pm 0.08^{\mathrm{B}}$ & $6.40 \pm 0.08^{\mathrm{A}}$ \\
\hline
\end{tabular}

PS - Isabel grape preparation added with sucrose. PAX - Isabel grape preparation added with agave and xylitol. FS -Isabel grape flour from the residue with sucrose. FAX - Isabel grape flour from the residue with agave and xylitol. $\mathbf{L}^{*}=$ luminosity. $\mathbf{a}^{*}=$ green - red. $\mathbf{b}^{*}=$ blue yellow. < LOD: below the limit of detection. ${ }^{\mathrm{a}, \mathrm{b}} \mathrm{Means} \pm$ standard deviations with different lowercase letters in the same row denote difference among the different preparation based on the Student t-test $(p \leq 0.05)$. ${ }^{\mathrm{A}, \mathrm{B}}$ Means \pm standard deviations with different uppercase letters in the same column denote difference among the different flour based on the Student t-test $(p \leq 0.05)$.

For the flours (Table 1), the formulation FS presented higher fructose content $(p \leq 0.05)$ than FAX, possibly due to the fructose from the breakdown of sucrose in FS. The presence of agave and xylitol used to sweeten the PAX and, consequently, the residue used to obtain FAX adds benefits to these products, because in addition to have similar or even higher sweetness than sucrose, they have a reduced calorie content (Santiago-García \& Lopez, 2014; Ur-Rehman et al., 2015). And are still recognized for presenting healthpromoting properties, including blood sugar reduction in diabetics (Ur-Rehman et al., 2015) and modulation of the intestinal microbiota (Santiago-García \& Lopez, 2014; Gurler et al., 2017). 
Tartaric acid was the organic acid with higher contents in all studied products, representing $55 \%$ to $67 \%$ of quantified total acid content. The tartaric and malic acids together represent more than $80 \%$ of total organic acids in grapes and derivatives (Coelho et al., 2018). According to Vilas Boas et al. (2014), these acids are predominant in grape juice, while citric and succinic have lower contents. The same can be observed for the preparations and the flours elaborated from Isabel grape in this study (Table 1).

\subsection{Instrumental color}

Regarding color parameters (Table 1), a* and $\mathrm{b}^{*}$ values did not differ $(p>0.05)$ among the preparations, while $L^{*}$ value related to luminosity was lower $(p \leq 0.05)$ for PS, thus demonstrating a slightly darker coloration for this formulation. The coloration of grape products, such as juices, pulps and the preparation, may show changes related to the influence of processing techniques (Gurak et al., 2010). For the flours, $L^{*}$ values did not differ $(p>0.05)$, since $\mathrm{b}^{*}$ value was lower $(p \leq 0.05)$ for FS, therefore showing a slightly blue coloration. The low values found for $\mathrm{L}^{*}$ indicate a product of darker coloration and low brightness, positive $\mathrm{a}^{*}$ values indicate red color, which may indicate a relationship with the stabilization of the pigment related to the flavylium cation by forming compounds derived from anthocyanin (Lago-Vanzela et al., 2014).

\subsection{Monomeric anthocyanins and antioxidant activity}

Table 2 shows higher levels of MA $(p \leq 0.05)$ in both the preparations and the flours when compared to the grape, which may indicate a beneficial effect of the processing on these compounds concentration. The conditions of moderate temperature for a short time used in heat treatment employed in preparation processing $\left(92.5^{\circ} \mathrm{C} / 3 \mathrm{~min}\right)$ are described for contributing with this compounds preservation since they facilitate their migration from the peel to the grape must, besides to deactivate enzymes responsible for its degradation (Silva et al., 2017). As well, compounds concentration by drying process used to obtain the flour probably had greater influence than possible degradation occurred in the same process.

Based on data presented in Table 2, we observed that in most of the samples, the highest antioxidant activity values were obtained by the ORAC method. These differences in results between methods are probably due to the different mechanisms involved in each of them (Silva et al., 2016). When compared to grapes, both preparations and flours presented higher $(p \leq 0.05)$ antioxidant activities, corroborating results found for anthocyanins, as mentioned above.

Regarding the antioxidant activity, the flours also highlighted compared to the preparations, showing values on average 4 times higher when evaluated by the ORAC method and up to 12 times higher by the FRAP method. Thus, evidencing its high antioxidant potential, as well as the possibility of its use as an alternative source of phytochemicals (Haas et al., 2018). According to Albuquerque et al. (2017), antioxidant activity is positively related to high levels of phenolic compounds. However, the profile composition of these compounds also exerts a great influence on this activity (Burin et al., 2014). The compounds with greatest contribution to antioxidant activities of grape products were catechin, epigallocatechin gallate, procyanidin B1 and B2, quercetin 3-glucoside, rutin, kaempferol glucoside, caffeic and caffeic acids, and transresveratrol, with the $\mathrm{r}$ ranging from 0.91 to 0.99 (Figure 1). Haas et al. (2018) observed high concentrations of catechins and a high correlation of these with antioxidant activity in grape processing residues, these compounds are recognized for their effect against free radicals and their chelating activity. 
Integral use of Isabel grapes to elaborate new products with nutritional value and functional potential

Silva, F. A. et al.

Table 2. Monomeric anthocyanins (MA) and antioxidant activity of Isabel grape, its preparation and flour.

\begin{tabular}{|c|c|c|c|c|c|c|c|c|c|}
\hline \multirow{2}{*}{ Parameters } & \multirow{2}{*}{ Grape } & \multicolumn{4}{|c|}{ Preparation } & \multicolumn{4}{|c|}{ Flour } \\
\hline & & PS & Var. (\%) & PAX & Var. (\%) & FS & Var. (\%) & FAX & Var. (\%) \\
\hline $\begin{array}{c}\text { Monomeric anthocy } \\
\text { (mg malvidin } \\
\text { 3-glucoside } \\
\left.100 \mathrm{~g}^{-1}\right)\end{array}$ & $23.45 \pm 0.61^{\mathrm{Bc}}$ & $33.12 \pm 0.26^{\mathrm{A}}$ & 41.24 & $33.71 \pm 0.88^{\mathrm{A}}$ & 43.75 & $35.63 \pm 1.04^{\mathrm{a}}$ & 51.95 & $31.81 \pm 0.75^{\mathrm{b}}$ & 35.65 \\
\hline \multicolumn{10}{|c|}{ Antioxidant activity $\left(\mu \mathrm{M}\right.$ TEAC $\left.100 \mathrm{~g}^{-1}\right)$} \\
\hline DPPH & $212.30 \pm 2.07^{\mathrm{Cc}}$ & $488.59 \pm 6.08^{\mathrm{A}}$ & 130.14 & $455.12 \pm 1.08^{\mathrm{B}}$ & 114.37 & $1954.40 \pm 0.62^{\mathrm{a}}$ & 820.57 & $1945.78 \pm 2.98^{b}$ & 816.51 \\
\hline FRAP & $541.30 \pm 2.89^{\mathrm{Bc}}$ & $957.65 \pm 12.48^{\mathrm{A}}$ & 121.63 & $593.38 \pm 1.05^{\mathrm{B}}$ & 37.32 & $7552.95 \pm 43.12^{\mathrm{b}}$ & 1647.97 & $12128.63 \pm 191.30^{\mathrm{a}}$ & 2706.91 \\
\hline ORAC & $1099.25 \pm 42.11^{\mathrm{Cc}}$ & $1798.12 \pm 9.20^{\mathrm{A}}$ & 63.58 & $1507.34 \pm 53.48^{\mathrm{B}}$ & 37.12 & $6457.80 \pm 212.26^{b}$ & 487.47 & $8598.33 \pm 120.08^{\mathrm{a}}$ & 682.20 \\
\hline
\end{tabular}

PS - Isabel grape preparation added with sucrose. PAX - Isabel grape preparation added with agave and xylitol. FS - Isabel grape flour from the residue with sucrose. FAX - Isabel grape flour from the residue with agave and xylitol. TEAC - trolox equivalent antioxidant activity.

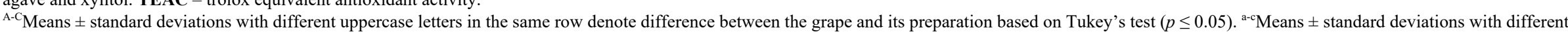
lowercase letters in the same row denote difference between the grape and its flour based on Tukey's test $(p \leq 0.05)$. 


\subsection{Phenolic profile before and after simulated digestion}

The phenolic profile of the grape and its products identified compounds belonging to the groups of flavanols, flavonols, phenolic acids and anthocyanins (Table 3). Among the quantified compounds before simulated digestion, the catechins content $\left(2.37-28.11 \mathrm{mg} 100 \mathrm{~g}^{-1}\right)$, which is recognized for its high antioxidant power (Burin et al., 2014), caftaric acid (2.31-69.43 mg $100 \mathrm{~g} \mathrm{~g}^{-1}$ ) and malvidin 3-glucoside

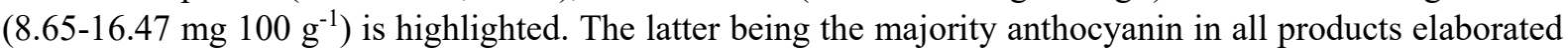
in this study, which according to Rockenbach et al. (2011) is the one found in larger quantities in red grapes since it is recognized as the most important for blue coloration (Rockenbach et al., 2011).

Most grape polyphenols are represented by anthocyanins, which are mainly concentrated in fruit peel and are responsible for the purple coloration of the grape since they are among the most important soluble pigments (Silva et al., 2016; Souza et al., 2015). Regarding flavanols, the compounds found in most of the samples were catechin and procyanidin B2, which, according to Lima et al. (2015), are directly associated with high antioxidant activity.

Catechin, epigallocatechin gallate and anthocyanin malvidin 3-glucoside reduced $(p \leq 0.05)$ their concentration from the grape to the preparation, as well as the caftaric and chlorogenic acids and the anthocyanins delphinidin 3-glucoside, pelargonidin 3-glucoside and peonidin 3-glucoside $(p \leq 0.05)$ in the preparation when compared to in natura grape. According to Lima et al. (2015), the maceration process used in grape juice elaboration is of great importance because it occurs in this phase the incorporation of the phenolic and aromatic compounds of the fruit in the juice, whereas in grape must heating occurs cellular wall rupture of the fruit, making easier the anthocyanins release. These processes are similar to those used in grape preparation elaboration in this study, which may explain the increase $(p \leq 0.05)$ of most anthocyanins in PS and PAX compared to in natura grape (Table 3).

Regarding the flours, the values of most compounds found in phenolic profile (Table 3 ) presented higher levels $(p \leq 0.05)$ than those found in the grape, probably due to effect of compounds concentration in the drying process, except procyanidin A2 and chlorogenic acid that were not detected in flours. In the anthocyanin profile, malvidin 3-glucoside had the value reduced $(p \leq 0.05)$ from the grape to the flours, while pelargonidin 3-glucoside and peonidin 3-glucoside were not detected in FAX, possibly because they were more sensitive to degradation, and can be affected by factors such as heat, oxygen, light, $\mathrm{pH}$ and enzymes (Pinto et al., 2017). This can also explain the lower concentration of anthocyanins in the flours when compared to the preparations (Table 3 ) since the heat used in the flour drying process can cause degradation of this group of compounds. While the preparation production process appears to be able to better preserve the anthocyanins and still increase its concentration when compared to the grape (Silva et al., 2017).

Principal Component Analysis (PCA) allowed for correlating grape products with antioxidant activity and phenolic compounds (Figure 1). For the initial fraction, the main components explained $96 \%$ of data variation, being $86 \%$ explained by PC1 and $10 \%$ by PC2. The malvidin 3 -glucoside, delphinidin 3 -glucoside, catechin, procyanidin $\mathrm{B} 1$ and $\mathrm{B} 2$, rutin, quercetin 3-glucoside, kaempferol glucoside, caffeic and caftaric acids, trans-resveratrol, DPPH, FRAP and ORAC showed a strong correlation with PC1, with the $\mathrm{r}$ ranging from 0.90 to 0.99 . While naringenin and gallic acid are negatively correlated with PC2, which has a strong association with FS by their higher content of these compounds. The preparations have a strong correlation with $\mathrm{PC} 1$ due to their higher anthocyanin concentrations, whereas flours have a strong association with antioxidant activities, corroborating the data presented in Table 2 . 
Table 3. Phenolic profile in grape, preparation and flour before and after in vitro gastrointestinal digestion.

\begin{tabular}{|c|c|c|c|c|c|c|c|c|c|c|}
\hline \multirow{2}{*}{ Compound } & \multicolumn{5}{|c|}{ Initial fraction $\left(\mathrm{mg} 100 \mathrm{~g}^{-1}\right)$} & \multicolumn{5}{|c|}{ Bioaccessible fraction (mg $\left.100 \mathrm{~g}^{-1}\right)$} \\
\hline & Grape & PS & PAX & FS & FAX & Grape & PS & PAX & FS & FAX \\
\hline \multicolumn{11}{|l|}{ Flavanols } \\
\hline Catechin & $2.91 \pm 0.04^{\mathrm{Ac}}$ & $2.64 \pm 0.04^{\mathrm{B}}$ & $2.37 \pm 0.04^{\mathrm{C}}$ & $21.09 \pm 0.34^{\mathrm{b}}$ & $28.11 \pm 0.46^{\mathrm{a}}$ & $3.98 \pm 0.06^{\mathrm{Ac}}$ & $4.00 \pm 0.06^{\mathrm{A}}$ & $4.00 \pm 0.06^{\mathrm{A}}$ & $5.73 \pm 0.09^{\mathrm{b}}$ & $6.29 \pm 0.10^{\mathrm{a}}$ \\
\hline Epigallocatechin gallate & $0.34 \pm 0.00^{\mathrm{Ac}}$ & $0.22 \pm 0.01^{\mathrm{B}}$ & $0.12 \pm 0.01^{\mathrm{C}}$ & $3.70 \pm 0.06^{\mathrm{b}}$ & $5.54 \pm 0.09^{\mathrm{a}}$ & $<\mathrm{LOD}$ & $0.21 \pm 0.00^{\mathrm{A}}$ & $0.03 \pm 0.00^{\mathrm{B}}$ & $0.05 \pm 0.00^{\mathrm{a}}$ & $0.05 \pm 0.00^{\mathrm{a}}$ \\
\hline Procyanidin B1 & $0.35 \pm 0.01^{\mathrm{Bc}}$ & $0.44 \pm 0.01^{\mathrm{A}}$ & $0.37 \pm 001^{\mathrm{B}}$ & $4.53 \pm 0.07^{b}$ & $6.37 \pm 0.10^{\mathrm{a}}$ & $0.03 \pm 0.00^{\mathrm{Cb}}$ & $0.32 \pm 0.00^{\mathrm{A}}$ & $0.29 \pm 0.00^{\mathrm{B}}$ & $0.56 \pm 0.01^{\mathrm{a}}$ & $0.55 \pm 0.01^{\mathrm{a}}$ \\
\hline Procyanidin B2 & $0.78 \pm 0.01^{\mathrm{Bc}}$ & $0.97 \pm 0.02^{\mathrm{A}}$ & $0.81 \pm 0.01^{\mathrm{B}}$ & $7.88 \pm 0.12^{\mathrm{b}}$ & $14.51 \pm 0.24^{\mathrm{a}}$ & $0.09 \pm 0.00^{\mathrm{Bb}}$ & $0.34 \pm 0.00^{\mathrm{A}}$ & $0.35 \pm 0.00^{\mathrm{A}}$ & $0.60 \pm 0.01^{\mathrm{a}}$ & $0.62 \pm 0.01^{\mathrm{a}}$ \\
\hline Procyanidin A2 & $0.49 \pm 0.01^{\mathrm{B}}$ & $0.87 \pm 0.01^{\mathrm{A}}$ & $<$ LOD & $<$ LOD & $<$ LOD & $<\mathrm{LOD}$ & $<$ LOD & $<$ LOD & $0.17 \pm 0.00^{\mathrm{a}}$ & $0.13 \pm 0.00^{\mathrm{b}}$ \\
\hline \multicolumn{11}{|l|}{ Flavonols } \\
\hline Quercetin glucoside & $0.46 \pm 0.01^{\mathrm{Bc}}$ & $0.59 \pm 0.01^{\mathrm{A}}$ & $0.56 \pm 0.01^{\mathrm{A}}$ & $1.18 \pm 0.02^{\mathrm{b}}$ & $1.30 \pm 0.02^{\mathrm{a}}$ & $0.03 \pm 0.00^{\mathrm{Ca}}$ & $0.08 \pm 0.00^{\mathrm{B}}$ & $0.09 \pm 0.00^{\mathrm{A}}$ & $<$ LOD & $<\mathrm{LOD}$ \\
\hline Rutin & $0.15 \pm 0.01^{\mathrm{Ac}}$ & $0.11 \pm 0.01^{\mathrm{B}}$ & $0.10 \pm 0.01^{\mathrm{B}}$ & $0.64 \pm 0.01^{\mathrm{b}}$ & $0.84 \pm 0.01^{\mathrm{a}}$ & & & & & \\
\hline Kaempferol glucoside & $0.11 \pm 0.01^{\mathrm{Bc}}$ & $0.13 \pm 0.01^{\mathrm{A}}$ & $0.13 \pm 0.01^{\mathrm{A}}$ & $0.29 \pm 0.01^{\mathrm{b}}$ & $0.39 \pm 0.01^{\mathrm{a}}$ & $<$ LOD & $0.01 \pm 0.00^{\mathrm{A}}$ & $0.01 \pm 0.00^{\mathrm{A}}$ & $0.05 \pm 0.00^{\mathrm{a}}$ & $0.03 \pm 0.00^{\mathrm{b}}$ \\
\hline Naringenin & $<\mathrm{LOD}$ & $0.21 \pm 0.01^{\mathrm{B}}$ & $0.24 \pm 0.01^{\mathrm{A}}$ & $0.36 \pm 0.01^{\mathrm{a}}$ & $0.25 \pm 0.01^{\mathrm{b}}$ & $<$ LOD & $<$ LOD & $<$ LOD & $<$ LOD & $<$ LOD \\
\hline Hesperidin & $<\mathrm{LOD}$ & $0.31 \pm 0.01^{\mathrm{A}}$ & $0.28 \pm 0.01^{\mathrm{B}}$ & $<\mathrm{LOD}$ & $<\mathrm{LOD}$ & $<\mathrm{LOD}$ & $<$ LOD & $<\mathrm{LOD}$ & $<\mathrm{LOD}$ & $<\mathrm{LOD}$ \\
\hline \multicolumn{11}{|l|}{ Phenolic acids } \\
\hline Gallic & $<\mathrm{LOD}$ & $<\mathrm{LOD}$ & $<\mathrm{LOD}$ & $1.81 \pm 0.03$ & $<\mathrm{LOD}$ & $0.41 \pm 0.01^{\mathrm{Cb}}$ & $0.48 \pm 0.01^{\mathrm{A}}$ & $0.45 \pm 0.01^{\mathrm{B}}$ & $0.73 \pm 0.01^{\mathrm{a}}$ & $0.76 \pm 0.01^{\mathrm{a}}$ \\
\hline Caffeic & $0.08 \pm 0.01^{\mathrm{Ac}}$ & $0.09 \pm 0.01^{\mathrm{A}}$ & $0.08 \pm 0.01^{\mathrm{A}}$ & $0.13 \pm 0.01^{\mathrm{b}}$ & $0.15 \pm 0.01^{\mathrm{a}}$ & $<\mathrm{LOD}$ & $<\mathrm{LOD}$ & $0.04 \pm 0.00^{\mathrm{A}}$ & $0.10 \pm 0.00^{\mathrm{a}}$ & $0.10 \pm 0.00^{\mathrm{a}}$ \\
\hline Caftaric & $2.31 \pm 0.04^{\mathrm{Cc}}$ & $38.43 \pm 0.63^{\mathrm{A}}$ & $35.86 \pm 0.58^{\mathrm{B}}$ & $63.65 \pm 1.04^{\mathrm{b}}$ & $69.43 \pm 1.13^{\mathrm{a}}$ & $0.03 \pm 0.00^{\mathrm{Cc}}$ & $1.17 \pm 0.02^{\mathrm{A}}$ & $1.07 \pm 0.02^{\mathrm{B}}$ & $1.89 \pm 0.03^{\mathrm{b}}$ & $2.13 \pm 0.03^{\mathrm{a}}$ \\
\hline Chlorogenic & $0.10 \pm 0.01^{\mathrm{C}}$ & $2.35 \pm 0.04^{\mathrm{A}}$ & $2.13 \pm 0.03^{\mathrm{B}}$ & $<\mathrm{LOD}$ & $<\mathrm{LOD}$ & $0.03 \pm 0.00^{\mathrm{Ba}}$ & $0.01 \pm 0.00^{\mathrm{C}}$ & $0.05 \pm 0.00^{\mathrm{A}}$ & $<\mathrm{LOD}$ & $<\mathrm{LOD}$ \\
\hline Trans-Resveratrol & $0.11 \pm 0.01^{\mathrm{Ac}}$ & $0.10 \pm 0.01^{\mathrm{A}}$ & $0.10 \pm 0.01^{\mathrm{A}}$ & $0.24 \pm 0.01^{\mathrm{b}}$ & $0.26 \pm 0.01^{\mathrm{a}}$ & $<\mathrm{LOD}$ & $0.04 \pm 0.00^{\mathrm{A}}$ & $0.02 \pm 0.00^{\mathrm{B}}$ & $0.05 \pm 0.00^{\mathrm{a}}$ & $0.04 \pm 0.00^{b}$ \\
\hline \multicolumn{11}{|l|}{ Anthocyanins } \\
\hline Delphinidin 3-glucoside & $0.19 \pm 0.01^{\mathrm{Cc}}$ & $0.92 \pm 0.02^{\mathrm{A}}$ & $0.86 \pm 0.01^{\mathrm{B}}$ & $0.51 \pm 0.01^{\mathrm{a}}$ & $0.44 \pm 0.01^{\mathrm{b}}$ & $<$ LOD & $<$ LOD & $<$ LOD & $<$ LOD & $<$ LOD \\
\hline Malvidin 3-glucoside & $16.47 \pm 0.27^{\mathrm{Aa}}$ & $15.06 \pm 0.24^{\mathrm{B}}$ & $14.08 \pm 0.23^{\mathrm{C}}$ & $10.68 \pm 0.17^{\mathrm{b}}$ & $8.65 \pm 0.14^{c}$ & $<\mathrm{LOD}$ & $<\mathrm{LOD}$ & $<\mathrm{LOD}$ & $<\mathrm{LOD}$ & $<\mathrm{LOD}$ \\
\hline Pelargonidin 3-glucoside & $1.33 \pm 0.02^{\mathrm{Cb}}$ & $2.45 \pm 0.04^{\mathrm{A}}$ & $2.31 \pm 0.04^{\mathrm{B}}$ & $1.72 \pm 0.03^{\mathrm{a}}$ & $<\mathrm{LOD}$ & $<\mathrm{LOD}$ & $<$ LOD & $<$ LOD & $<\mathrm{LOD}$ & $<$ LOD \\
\hline Peonidin 3-glucoside & $2.10 \pm 0.03^{\mathrm{Ca}}$ & $2.49 \pm 0.04^{\mathrm{A}}$ & $2.31 \pm 0.04^{\mathrm{B}}$ & $1.85 \pm 0.03^{\mathrm{b}}$ & $<\mathrm{LOD}$ & $<\mathrm{LOD}$ & $<$ LOD & $<$ LOD & $<$ LOD & $<$ LOD \\
\hline
\end{tabular}

PS - Isabel grape preparation added with sucrose. PAX - Isabel grape preparation added with agave and xylitol. FS - Isabel grape flour from the residue with sucrose. FAX - Isabel grape flour from the residue with agave and xylitol. < LOD: below the limit of detection. ${ }^{\mathrm{A}-\mathrm{C}}$ Means \pm standard deviations with different uppercase letters in the same row denote difference between the grape and its preparation based on Tukey's test $(p \leq 0.05) .{ }^{a-c}$ Means \pm standard deviations with different lowercase letters in the same row denote difference between the grape and its flour based on Tukey's test $(p \leq 0.05)$. 

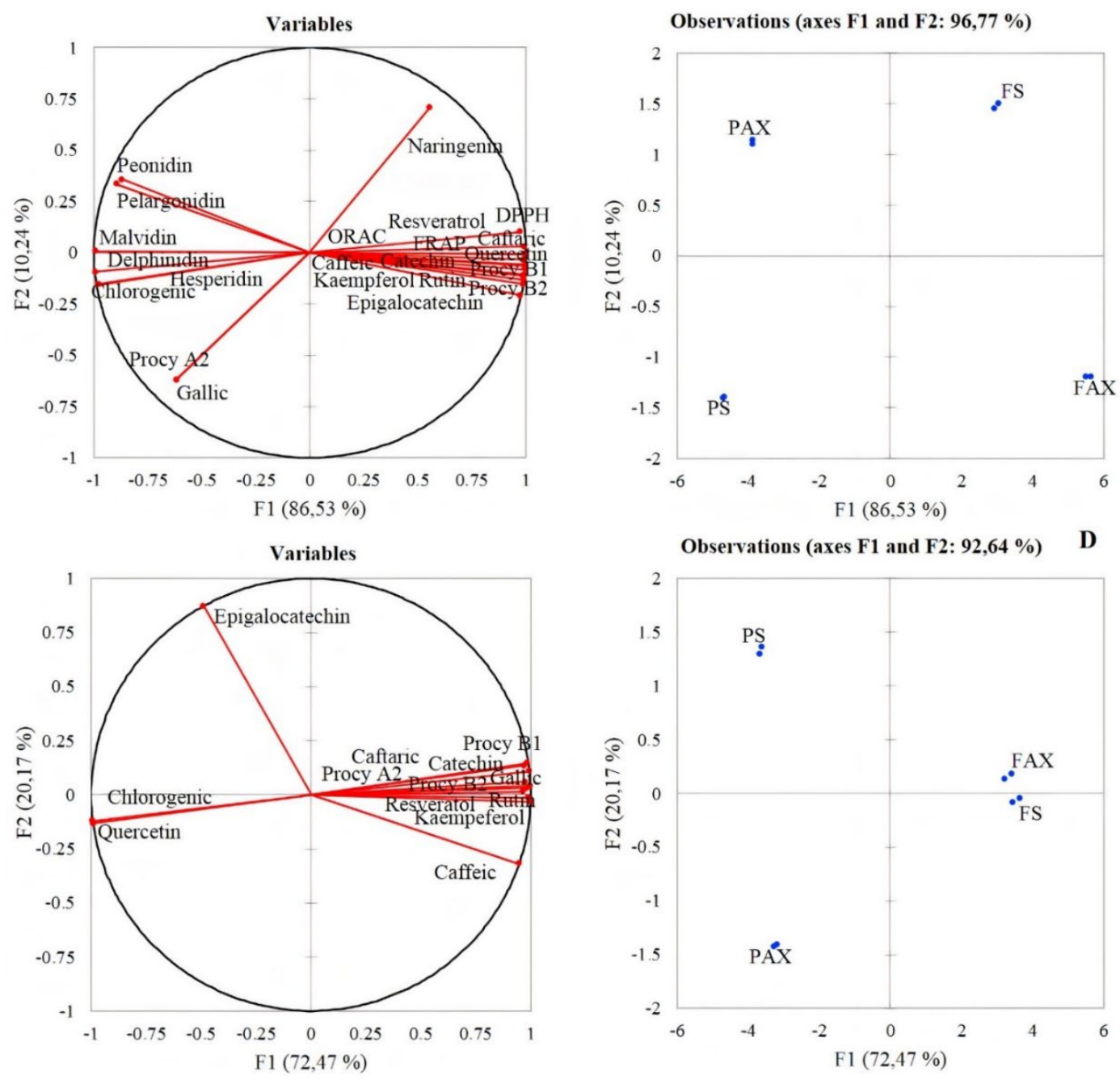

Figure 1. Principal component analysis (PCA) of the phenolic compounds and antioxidant activity before simulated digestion (A) and phenolic compounds after simulated digestion (C) of the Isabel grape preparations and flours. Distribution of the Isabel grape preparations and flours according to PCA (B, D). PS - Isabel grape preparation added with sucrose. PAX - Isabel grape preparation added with agave and xylitol. FS -Isabel grape flour from the residue with sucrose. FAX - Isabel grape flour from the residue with agave and xylitol.

The flavonols naringenin and hesperidin and the anthocyanins delphinidin 3-glucoside, malvidin 3-glucoside, pelargonidin 3-glucoside and peonidin 3-glucoside were not detected (data not shown) on HPLC analysis in any of the samples after simulated digestion process, which indicates these compounds instability concerning to conditions to which they were submitted. These compounds did not resist the simulated digestion process, possibly because they oxidized due to $\mathrm{pH}$ conditions and enzymes found in the digestion process (Pinto et al., 2017).

However, it was not a common result for all analyzed samples, we observed a variation from one product to another, as can be seen in Table 3, evidencing food matrix influence on compounds protection during passage through the gastrointestinal tract. This relation with the matrix represents one of the factors that most interferes with phenolic compounds bioaccessibility. On the one hand, it can hinder their release and give rise to unavailable forms through chemical modifications. In contrast, this interaction may have a protective effect, preventing the degradation of the compounds (Ribas-Agustí et al., 2018). As for digestion process variables such as rupture by mechanical action, $\mathrm{pH}$ and enzymes of the gastrointestinal tract can also facilitate its release (Dantas et al., 2019). 
For the digested fraction, the data variation was explained by $92 \%$ for the main components, being $72 \%$ for $\mathrm{PC} 1$ and $20 \%$ for PC2 (Figure 1). The strongest correlation with PC1 was from catechin, procyanidin B1 and $\mathrm{B} 2$, procyanidin $\mathrm{A} 2$, gallic acid, caftaric acid, rutin and trans-resveratrol, while epigallocatechin gallate had the highest correlation with PC2. Regarding the products, PS is strongly associated with PC2 due to its higher epigallocatechin gallate levels.

\subsection{Phenolic compounds bioaccessibility}

Phenolic compounds have a recognized antioxidant activity, however, it is also important to evaluate their bioaccessibility, since it will influence this activity. Digestion step may affect these compounds' bioaccessibility concerning several factors, among them the food matrix, which will influence the stability of the compounds, as well as the portion that will be absorbed or will continue to the colon (Gomes et al., 2019).

In general, catechin was the compound with the highest bioaccessibility ( $22 \%$ to $168 \%$ ), whereas the preparations showed higher bioaccessibility of the compounds in relation to grapes and flours (Figure 2), with the latter presenting higher values only for caffeic acid ( $\sim 78$ and $63 \%$ in FS and FAX, respectively) and trans-resveratrol ( $\sim 22$ and 17\% in FS and FAX, respectively). The digestive and intestinal enzymes found in the digestion process are recognized for making easier the phenolic compounds release bounded to a food matrix, which may justify the increased catechins bioaccessibility due to partial proanthocyanins hydrolysis caused by intestinal $\mathrm{pH}$. As the rearrangement of some compounds is possibly responsible for this increase in certain phenolic acids (Mosele et al., 2016; Dutra et al., 2017).

Gallic acid also presented considerable bioaccessibility values ranging from $40 \%$ to $75 \%$ among the products (Figure 2). This acid can be found in large quantities in grapes, wine and other different fruits. It has been highlighted as a potent antioxidant, also exhibiting anti-inflammatory and anti-cancer functions (Punithavathi et al., 2011). Due to the many benefits that can be provided to health, foods rich in phenolic compounds with high bioaccessibility can attract consumers' attention to implement their feeding with these products addition, as well as allowing for value aggregation to them, which may provide greater return for the producers (Cilla et al., 2018).

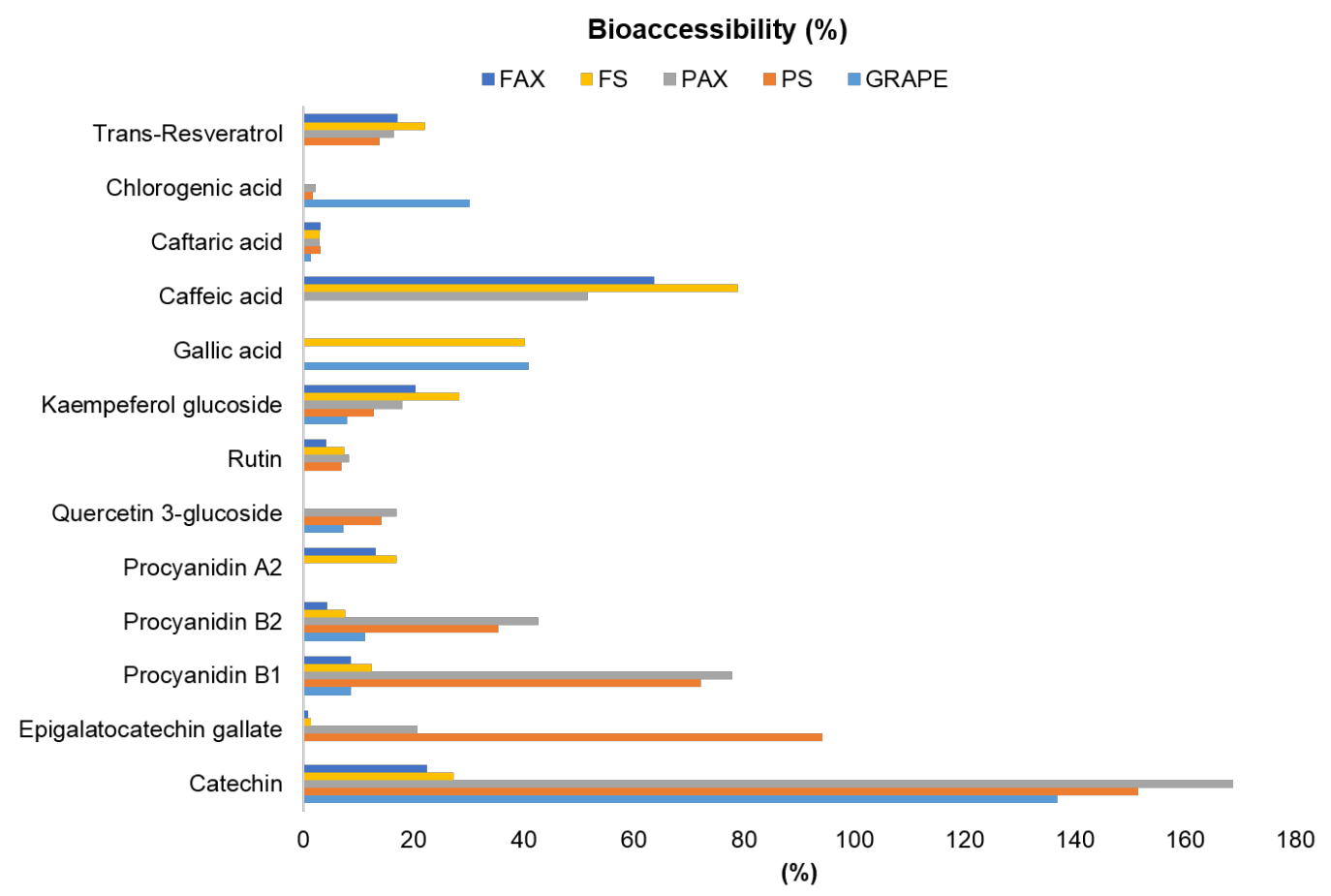

Figure 2. Phenolic compounds bioaccessibility of the Isabel grape, its preparation and flour. FAX - Isabel grape flour from the residue with agave and xylitol. FS -Isabel grape flour from the residue with sucrose. PAX - Isabel grape preparation added with agave and xylitol. PS - Isabel grape preparation added with sucrose. GRAPE - Isabel grape in natura. 
Similarly, to what was observed in this study, Dantas et al. (2019) found that the group of phenolic acids and flavonoids presented greater bioaccessibility than anthocyanins when studied the bioaccessibility of red fruit pulps. Also, a significant reduction of anthocyanin contents after digestion simulation was observed since the pulps of blackberry, jabuticaba and açaí did not present bioaccessible anthocyanins after simulated digestion in the gastrointestinal tract. Anthocyanins are among the compounds most sensitive to simulated digestion process, with great degradation occurring during the intestinal stage. Its chemical form will vary according to $\mathrm{pH}$ of the solution, the acidic $\mathrm{pH}$ of the stomach generally favors its stability, but the $\mathrm{pH}$ increase in the intestine can originate the colorless chalcone form that is more sensitive, which may justify this compound degradation during digestion (Pinto et al., 2017).

\section{Conclusion}

Isabel grape and its products presented an interesting profile of phenolic compounds, especially the flours, which exhibited a concentration of these due to the drying process, in addition to the relevant fiber content also presented by flour. The beneficial effect of grape processing is emphasized, since both the preparations and the flours presented good bioaccessibility for most of the compounds and higher values of anthocyanins and antioxidant activity than the in natura grape, thus favoring the beneficial health properties that can be allocated to those products and suggesting their potential as functional ingredients in foods. Besides the integral grape use contribute to the lower environmental impact of fruit residues and the concept of a circular economy.

\section{Acknowledgements}

The authors thank the Laboratory of Experimentation and Food Analysis of the Nutrition Department of the Federal University of Pernambuco - LEAAL/UFPE.

\section{References}

Akesowan, A. (2015). Optimization of textural properties of konjac gels formed with K-carrageenan or xanthan and xylitol as ingredients in jelly drink processing. Journal of Food Processing and Preservation, 39(6), 1735-1743. http://dx.doi.org/10.1111/jfpp.12405

Albuquerque, J. G. F., Assis, V. L., Almeida, A. J. P. O., Basílio, I. J. L. D., Luciano, M. N., Meireles, B. R. L. A., Cordeiro, A. M. T. M., Araújo, I. G. A., Veras, R. C., Ribeiro, T. P., \& Medeiros, I. A. (2017). Antioxidant and vasorelaxant activities induced by northeastern Brazilian fermented grape skins. BMC Complementary and Alternative Medicine, 17(1), 376. PMid:28754099. http://dx.doi.org/10.1186/s12906-017-1881-2

Association of Official Analytical Chemists - AOAC. (2016). Official methods of analysis (20th ed.). Gaithersburg: AOAC.

Ball, S., Bullock, S., Lloyd, L., Mapp, K. P., \& Ewen, A. (2011). Analysis of carbohydrates, alcohols, and organic acids by ionexchange chromatography: Agilent Hi-Plex columns applications compendium. Santa Clara: Agilent Technologies Inc.

Batista, K. S., Alves, A. F., Lima, M. D. S., Silva, L. A., Lins, P. P., Gomes, J. A. S., Silva, A. S., Toscano, L. T., Meireles, B. R. L. A., Cordeiro, A. M. T. M., Conceição, M. L., Souza, E. L., \& Aquino, J. S. (2018). Beneficial effects of consumption of acerola, cashew or guava processing by-products on intestinal health and lipid metabolism in dyslipidaemic female Wistar rats. British Journal of Nutrition, 119(1), 30-41. PMid:29355095. http://dx.doi.org/10.1017/S0007114517003282

Bender, A. B. B., Luvielmo, M. M., Loureiro, B. B., Speroni, C. S., Boligon, A. A., Silva, L. P., \& Penna, N. G. (2016). Obtention and characterization of grape skin flour and its use in an extruded snack. Brazilian Journal of Food Technology, 19(10), 1-10.

Brand-Williams, W., Cuvelier, M. E., \& Berset, C. (1995). Use of a free radical method to evaluate antioxidant activity. Lebensmittel-Wissenschaft + Technologie, 281(1), 25-30. http://dx.doi.org/10.1016/S0023-6438(95)80008-5

Burin, V. M., Ferreira-Lima, N. E., Panceri, C. P., \& Bordignon-Luiz, M. T. (2014). Bioactive compounds and antioxidant activity of Vitis vinifera and Vitis labrusca grapes: Evaluation of different extraction methods. Microchemical Journal, 114, 155-163. http://dx.doi.org/10.1016/j.microc.2013.12.014

Cilla, A., Bosch, L., Barberá, R., \& Alegría, A. (2018). Effect of processing on the bioaccessibility of bioactive compounds: A review focusing on carotenoids, minerals, ascorbic acid, tocopherols and polyphenols. Journal of Food Composition and Analysis, 68, 3-15. http://dx.doi.org/10.1016/j.jfca.2017.01.009

Coelho, E. M., Padilha, C. V. S., Miskinis, G. A., Sá, A. G. B., Pereira, G. E., Azevêdo, L. C., \& Lima, M. L. (2018).

Simultaneous analysis of sugars and organic acids in wine and grape juices by HPLC: Method validation and characterization of products from northeast Brazil. Journal of Food Composition and Analysis, 66, 160-167.

http://dx.doi.org/10.1016/j.jfca.2017.12.017 
Dantas, A. M., Mafaldo, I. M., Oliveira, P. M. L., Lima, M. S., Magnani, M., \& Borges, G. S. C. (2019). Bioaccessibility of phenolic compounds in native and exotic frozen pulps explored in Brazil using a digestion model coupled with a simulated intestinal barrier. Food Chemistry, 274, 202-214. PMid:30372928. http://dx.doi.org/10.1016/j.foodchem.2018.08.099

Dutra, M. C. P., Rodrigues, L. L., Oliveira, D., Pereira, G. E., \& Lima, M. S. (2018). Integrated analyses of phenolic compounds and minerals of Brazilian organic and conventional grape juices and wines: Validation of a method for determination of $\mathrm{Cu}, \mathrm{Fe}$ and Mn. Food Chemistry, 269, 157-165. PMid:30100418. http://dx.doi.org/10.1016/j.foodchem.2018.07.014

Dutra, R. L., Dantas, A. M., Marques, D. A., Batista, J. D. F., Meireles, R. L. A., Cordeiro, A. M. T. M., Magnani, M., \& Borges, G. S. C. (2017). Bioaccessibility and antioxidant activity of phenolic compounds in frozen pulps of Brazilian exotic fruits exposed to simulated gastrointestinal conditions. Food Research International, 100(Pt 1), 650-657. PMid:28873733.

http://dx.doi.org/10.1016/j.foodres.2017.07.047

Food and Agriculture Organization - FAO. Codex Alimentarius Commission. (2010). Codex alimentarius (CODEX) guidelines on nutrition labeling CAC/GL 2-1985 as last amended 2010. Rome: FAO.

Giusti, M. M., \& Wrolstad, R. E. (2001). Antocyanins: Characterization and measurement with uv-visible spectroscopy. In R. E. Wrolstad (Ed.), Current protocols in food analytical chemistry. New York: John Wiley \& Sons.

Gomes, T. M., Toaldo, I. M., Haas, I. C. S., Burin, V. M., Caliari, V., Luna, A. S., de Gois, J. S., \& Bordignon-Luiz, M. T. (2019). Differential contribution of grape peel, pulp, and seed to bioaccessibility of micronutrients and major polyphenolic compounds of red and white grapes through simulated human digestion. Journal of Functional Foods, 52, 699-708. http://dx.doi.org/10.1016/j.jff.2018.11.051

Gurak, P. D., Cabral, L. M. C., Rocha-Leão, M. H. M., Matta, V. M., \& Freitas, S. P. (2010). Quality evaluation of grape juice concentrated by reverse osmosis. Journal of Food Engineering, 96(3), 421-426.

http://dx.doi.org/10.1016/j.jfoodeng.2009.08.024

Gurler, E. B., Ozbeylđ, D., Buzcu, H., Bayraktar, S., Carus, D., Dağ, B., Gerđs, Y., Jeral, S., \& Yeğen, B. C. (2017). Natural sweetener agave inhibits gastric emptying in rats by a cholecystokinin-2- and glucagon like peptide-1 receptor-dependent mechanism. Food \& Function, 8(2), 741-745. PMid:28106207. http://dx.doi.org/10.1039/C6FO01438K

Haas, I. C. S., Toaldo, I. M., Burin, V. M., \& Bordignon-Luiz, M. T. (2018). Extraction optimization for polyphenolic profiling and bioactive enrichment of extractives of non-pomace residue from grape processing. Industrial Crops and Products, 112, 593-601. http://dx.doi.org/10.1016/j.indcrop.2017.12.058

Lago-Vanzela, E. S., Procópio, D. P., Fontes, E. A. F., Ramos, A. M., Stringheta, P. C., Da-Silva, R., Castillo-Muñoz, N., \& Hermosín-Gutiérrez, I. (2014). Aging of red wines made from hybrid grape cv. BRS Violeta: Effects of accelerated aging conditions on phenolic composition, color and antioxidant activity. Food Research International, 56, 182-189. http://dx.doi.org/10.1016/j.foodres.2013.12.030

Lima, M. S., Dutra, M. C. P., Toaldo, I. M., Correa, L. C., Pereira, G. E., Oliveira, D., Bordignon-Luiz, M. T., \& Ninow, J. L. (2015). Phenolic compounds, organic acids and antioxidant activity of grape juices produced in industrial scale by different processes of maceration. Food Chemistry, 188, 384-392. PMid:26041208. http://dx.doi.org/10.1016/j.foodchem.2015.04.014

Mosele, J. I., Macià, A., Romero, M. P., \& Motilva, M. J. (2016). Stability and metabolismo of Arbutus unedo bioactive compounds (phenolics and antioxidants) under in vitro digestion and colonic fermentation. Food Chemistry, 201, 120-130. PMid:26868556. http://dx.doi.org/10.1016/j.foodchem.2016.01.076

Pešić, M. B., Milinčić, D. D., Kostić, A. Ž., Stanisavljević, N. S., Vukotić, G. N., Kojić, M. O., Gašić, U. M., Barać, M. B., Stanojević, S. P., Popović, D. A., Banjac, N. R., \& Tešić, Ž. L. (2019). In vitro digestion of meat- and cereal-based food matrix enriched with grape extracts: How are polyphenol composition, bioaccessibility and antioxidante activity affected? Food Chemistry, 284, 28-44. PMid:30744859. http://dx.doi.org/10.1016/j.foodchem.2019.01.107

Pintać, D., Majkić, T., Torović, L., Orčić, D., Beara, I., Simin, N., Mimica-Dukić, N., \& Lesjak, M. (2018). Solvent selection for efficient extraction of bioactive compounds from grape Pomace. Industrial Crops and Products, 111, 379-390. http://dx.doi.org/10.1016/j.indcrop.2017.10.038

Pinto, J., Spínola, V., Llorent-Martínez, E. J., Fernández-de Córdova, M. L., Molina-García, L., \& Castilho, P. C. (2017). Polyphenolic profile and antioxidant activities of Madeiran elderberry (Sambucus lanceolata) as affected by simulated in vitro digestion. Food Research International, 100(3), 404-410. PMid:28964363. http://dx.doi.org/10.1016/j.foodres.2017.03.044

Pizzolato, S., Andrada, M., Rinaldoni, A. N., \& Campderros, M. (2012). Process for integral use of blueberry. International Journal of Food Engineering, 8(4). http://dx.doi.org/10.1515/1556-3758.2415

Punithavathi, V. R., Prince, P. S. M., Kumar, R., \& Selvakumari, J. (2011). Antihyperglycaemic, antilipid peroxidative and antioxidant effects of gallic acid on streptozotocin induced diabetic Wistar rats. European Journal of Pharmacology, 650(1), 465471. PMid:20863784. http://dx.doi.org/10.1016/j.ejphar.2010.08.059

Ribas-Agustí, A., Martín-Belloso, O., Soliva-Fortuny, R., \& Elez-Martínez, P. (2018). Food processing strategies to enhance phenolic compounds bioaccessibility and bioavailability in plant-based foods. Critical Reviews in Food Science and Nutrition, 58(15), 2531-2548. PMid:28609142.

Rockenbach, I. I., Rodrigues, E., Gonzaga, L. V., Caliari, V., Genovese, M. I., Gonçalves, A. E. S. S., \& Fett, R. (2011). Phenolic compounds content and antioxidant activity in pomace from selected red grapes (Vitis vinifera L. and Vitis labrusca L.) widely produced in Brazil. Food Chemistry, 127(1), 174-179. http://dx.doi.org/10.1016/j.foodchem.2010.12.137

Rufino, M. D. S. M., Alves, R. E., Brito, E. S., Morais, S. M., Sampaio, C. D. G., Pérez-Jiménez, J., \& Saura-Colixto, F. D. (2006). Metodologia científica: Determinação da atividade antioxidante total em frutas pelo método de redução do ferro (FRAP) (Comunicado Técnico Embrapa, No. 125, pp. 1-4). Fortaleza: Embrapa Agroindústria Tropical. 
Santiago-García, P. A., \& Lopez, M. G. (2014). Agavins from Agave angustifolia and Agave potatorum affect food intake, body weight gain and satiety related hormones (GLP-1 and ghrelin) in mice. Food \& Function, 5(12), 3311-3319. PMid:25367106. http://dx.doi.org/10.1039/C4FO00561A

Selani, M. M., Brazaca, S. G. C., Dias, C. T. S., Ratnayake, W. S., Flores, R. A., \& Bianchini, A. (2014). Characterization and potential application of pineapple pomace in an extruded product for fibre enhancement. Food Chemistry, 163, 23-30. PMid:24912691. http://dx.doi.org/10.1016/j.foodchem.2014.04.076

Sette, P., Fernandez, A., Soria, J., Rodriguez, R., Salvatori, D., \& Mazza, G. (2020). Integral valorization of fruit waste from wine and cider industries. Journal of Cleaner Production, 242, 118486. http://dx.doi.org/10.1016/j.jclepro.2019.118486

Silva, F. A., Oliveira, M. E. G., Figueirêdo, R. M. F., Sampaio, K. B., Souza, E. L., Oliveira, C. E. V., Pintado, M. M. E., \& Queiroga, R. C. R. E. (2017). The effect of Isabel grape addition on the physicochemical, microbiological and sensory characteristics of probiotic goat milk yogurt. Food \& Function, 8(6), 2121-2132. PMid:28451663. http://dx.doi.org/10.1039/C6FO01795A

Silva, J. K., Cazarin, C. B. B., Correa, L. C., Batista, A. G., Furlan, C. P. B., Biasoto, A. C. T., Pereira, G. E., Camargo, A. C., \& Maróstica Junior, M. R. (2016). Bioactive compounds of juices from two Brazilian grape cultivars. Journal of the Science of Food and Agriculture, 96(6), 1990-1996. PMid:26084730. http://dx.doi.org/10.1002/jsfa.7309

Sousa, E. C., Uchôa-Thomaz, A. M. A., Carioca, J. O. B., Morais, S. M., Lima, A., Martins, C. G., Alexandrino, C. D., Ferreira, P. A. T., Rodrigues, A. L. M., Rodrigues, S. P., Silva, J. N., \& Rodrigues, L. L. (2014). Chemical composition and bioactive compounds of grape pomace (Vitis vinifera L.), Benitaka variety, grown in the semiarid region of Northeast Brazil. Food Science and Technology (Campinas), 34(1), 135-142. http://dx.doi.org/10.1590/S0101-20612014000100020

Souza, B. V., Thomazini, M., Balieiro, J. C. C., \& Fávaro-Trindade, C. S. (2015). Effect of spray drying on the physicochemical properties and color stability of the powdered pigment obtained from vinification byproducts of the Bordo grape (Vitis labrusca). Food and Bioproducts Processing, 93, 39-50. http://dx.doi.org/10.1016/j.fbp.2013.11.001

Ur-Rehman, S., Mushtaq, Z., Zahoor, T., Jamil, A., \& Murtaza, M. A. (2015). Xylitol: A review on bio-production, application, health benefits and related safety issues. Critical Reviews in Food Science and Nutrition, 55(11), 1514-1528. PMid:24915309. http://dx.doi.org/10.1080/10408398.2012.702288

Valero-Cases, E., \& Frutos, M. J. (2017). Development of prebiotic nectars and juices as potential substrates for Lactobacillus acidophilus: Special reference to physicochemical characterization and consumer acceptability during storage. LebensmittelWissenschaft + Technologie, 81, 136-143. http://dx.doi.org/10.1016/j.Iwt.2017.03.047

Viana, E. S., Mamede, M. E. O., Reis, R. C., Carvalho, L. D., \& Fonseca, M. D. (2015). Desenvolvimento de geleia de umbucajá tradicional e dietética. Revista Brasileira de Fruticultura, 37(3), 708-717. http://dx.doi.org/10.1590/0100-2945-018/14

Vilas Boas, A. C., Henrique, P. C., Lima, L. C. O., \& Decarlos Neto, A. (2014). Antioxidant activity, anthocyanins and organic acids content of grape juices produced in southwest of Minas Gerais, Brazil. Ciência e Agrotecnologia, 38(5), 480-486. http://dx.doi.org/10.1590/S1413-70542014000500007

Zulueta, A., Esteve, M. J., \& Frigola, A. (2009). ORAC and TEAC assays comparison to measure the antioxidant capacity of food products. Food Chemistry, 114(1), 310-316. http://dx.doi.org/10.1016/j.foodchem.2008.09.033

Funding: This research was supported by CAPES-Brazil under grant (number 1734/2015); PROPESQ-UFPE under grant (number 23076.049914/2017-47) and CNPq-Brazil with a scholarship to the first author. 